\title{
INTEGRATED VEGETATION MANAGEMENT ON AN ELECTRIC TRANSMISSION RIGHT-OF-WAY IN SOUTHEASTERN PENNSYLVANIA, U.S.
}

\author{
By Richard H. Yahner ${ }^{1}$ and Russell J. Hutnik ${ }^{2}$
}

Abstract. Integrated Vegetation Management (IVM) via the wireborder zone method has been used for the maintenance of vegetation along an electric utility transmission right-of-way (ROW) at the Green Lane Research and Demonstration Area, Montgomery County, Pennsylvania, U.S., since 1987. The wireborder zone method creates a forb-grass-short shrub cover type in wire zones and a tall shrub cover type in border zones. The Green Lane Research and Demonstration Area has been studied annually since 1987, which makes this 18-year-old project one of the longest continuous studies documenting the effects of mechanical and herbicidal maintenance on flora and fauna along an electric transmission ROW. In this paper, our objective is to present target (undesirable) tree density and cover-type development in response to IVM prior to the most recent treatment (June 1999) and 4 to 5 years after treatment. Excellent control of target trees was noted in 1999 in wire zones of mowing plus herbicide units; in contrast, tree control was poor in wire zones of mechanical units (mowing and handcut). Maximum tree height averaged $4.3 \mathrm{~m}$ (14 ft) and $4.9 \mathrm{~m}$ (16 ft) in wire and border zones, respectively. Immediately prior to the 1999 treatment of the Green Lane ROW, cover types in wire zones of herbicidal units (mowing plus herbicide, stem-foliage spray, and foliage spray) were classified as shrub-forb-grass-tree, whereas types in border zones of these units were tree-shrub-forb. Both wire and border zones of mechanical units were considered tree-shrub-forb cover type. The overall density of target trees increased $7.3 \%$ and $26.4 \%$ in wire zones and border zones, respectively, in 2004 compared to 2003. From 1999-2004, the most common target tree species on the Green Lane ROW was white ash (Fraxinus americana). In both 2003 and 2004, shrubs and forbs were the most important cover types in wire zones of all treatment units; grass cover type, however, was important in wire zones of five of the ten units. IVM of a ROW is a "tree resistant" but not a "tree proof" means of reducing tree invasion. Competition with existing plants and wildlife predation on tree seeds on a ROW managed via the wire-border zone method keeps tree invasion to a minimum. Thus, over the years since 1987, IVM and the wireborder zone method of ROW maintenance have increased the time between treatment cycles, thereby reducing labor and chemical costs for ROW maintenance.

Key words. Cover type; herbicide; Integrated Vegetation Management; right-of-way; tree control; vegetation, wireborder zone method.

Integrated Vegetation Management (IVM) via the wire-border zone method has been used for vegetative maintenance along an electric utility transmission right-of-way (ROW) at the
Green Lane Research and Demonstration Area, Montgomery County, Pennsylvania, U.S., since 1987 (Bramble and Brynes 1996; Yahner and Hutnik 2004a). IVM comprises two treatment phases: (1) use of herbicidal sprays or mechanical treatments to eliminate target (undesirable) tree species (i.e., those that have the potential of growing to a height that is not compatible with safe ROW maintenance), and (2) development of tree-resistant plant cover types to reduce invasion of the ROW by target tree species (Bramble and Byrnes 1996; Yahner and Hutnik 2004b).

The wire-border zone method was implemented on the ROW in 1987 (Figure 1) (Yahner and Hutnik 2004a; see also Yahner and Hutnik 2004b). This method creates forbgrass-short shrub cover type in wire zones and shrub cover type in border zones (Bramble et al. 1991), thereby producing a ROW with economic, aesthetic, and wildlife benefits (Yahner 2004). Recently, electric utility companies have recommended the use of the wire-border zone method and IVM for maintenance of vegetation along transmission ROW (Burns 2004). In this paper, our objective was to present target tree density and cover-type development on the ROW at the Green Lane Research and Demonstration Area in response to IVM prior to the most recent treatment (1999) and 4 to 5 years after treatment.

\section{STUDY AREA AND TREATMENT METHODS}

The Green Lane Research and Demonstration Area is located along a 500-kV transmission ROW of PECO in the Piedmont Region of southeastern Pennsylvania (Yahner and

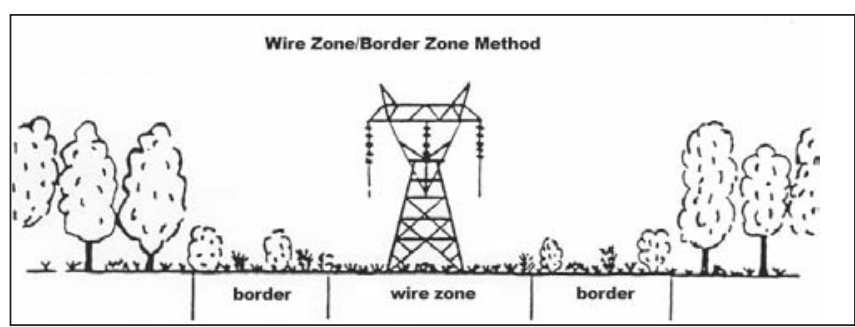

Figure 1. Diagram of a 500-kV electric transmission line, showing wire and border zones. A combination of a low-growing forb-grass-shrub cover type develops in wire zones, and a tall shrub cover type occurs in border zones. Adjacent to the border zone is mature forest. 
Hutnik 2004a). Treatment units on the ROW are rectangular in shape, 0.32 to 1 ha ( 0.8 to $2.47 \mathrm{ac}$ ) each, and span the entire width of the ROW.

In 1987, five treatments were applied: handcut, mowing, mowing plus herbicide, foliage spray, and stemfoliage spray (Yahner and Hutnik 2004a). In the handcut unit, woody vegetation was cut to a $10 \mathrm{~cm}$ (4 in.) height in wire zones, and undesirable trees were cut in border zones. In mowing units, vegetation was mowed in wire zones. In mowing plus herbicide units, vegetation was mowed in wire zones, and a broadcast spray was applied immediately using a mix of Tordon K (0.75\%), Garlon 3A $(0.75 \%)$, water, and blue dye. In foliage spray units, Accord, Clean Cut, and 38F in water was applied to the foliage of all trees and tall shrubs in wire zones. In stemfoliage spray units, a selective stem-foliage spray of Tordon 101, Garlon 3A (0.5\%), water, and blue dye was applied to all trees and tall shrubs in wire zones. In border zones of mowing, mowing plus herbicide, foliage spray, and stem-foliage spray units, a low-volume selective basal spray was applied to target trees using Access and Garlon 4 in Arborchem basal oil.

Six treatments were applied in 1993, including the same five used in an earlier treatment of the ROW in 1987 plus a Krenite treatment (Yahner and Hutnik 2004a). In 1993, the handcut unit was treated as in 1987, but one-third of the handcut unit was given a selective foliage spray using Krenite $\mathrm{S}$ and water in wire zones; a selective foliage spray was applied in border zones to trees consisting of Garlon 3A, Escort, and surfactant $41 \mathrm{~A}$ in water. In 1993, wire zones in the mowing units were treated as in 1987; however, wire zones in mowing plus herbicide units did not need retreatment, wire zones in foliage spray units were treated with Garlon 3A and water, and wire zones in stem-foliage spray units were treated with Accord and surfactant in water. Also in 1993, border zones in mowing, mowing plus herbicide, and foliage spray units were given a low-volume selective basal spray of Garlon 4 and Arsenal in basal oil.

Five treatments were applied in 1999 to the Green Lane Research and Demonstration Area: handcut, mowing, mowing plus herbicide, stem-foliage spray, and foliage spray (Yahner and Hutnik 2004b). In 1999, the Krenite spray unit in the 1993 treatment was reincorporated into the original handcut unit, and this unit was cut as in previous treatments. Wire zones of mowing units were treated as in 1987, and border zones of these units and those of the following three treatment units were treated with a low-volume selective basal spray of Garlon 4 in Arborchem basal oil. Wire zones in mowing plus herbicide units were cut as in the 1987 treatment and then sprayed 10 weeks later with Tordon $\mathrm{K}$ and Thinvert in water. Trees and tall shrubs in wire zones of stem- foliage spray units were treated with Garlon 3A and Tordon $\mathrm{K}$ in water; trees and tall shrubs in wire zones of foliage spray units were treated with Accord and Chemsurf 80 in water.

\section{VEGETATION MEASUREMENTS}

Vegetation was measured on the Green Lane Research and Demonstration Area during May to mid-June in 1999, 2003, and 2004 (Yahner et al. 1999, 2003b; Yahner and Hutnik 2004a). We counted target (undesirable) trees at least $0.3 \mathrm{~m}(1 \mathrm{ft})$ in height within two permanent transect belts (each $20 \mathrm{~m}$ [66 ft] long $\times 2 \mathrm{~m}$ [6.6 ft] wide) in wire zone and within two to three corresponding permanent transect belts (each $10 \mathrm{~m}$ [33 ft] long $\times 2 \mathrm{~m}$ [6.6 ft] wide) that extended east from wire zone transects and into adjacent border zones. Vegetation in the east border zone only was measured because the west border zone on the Green Lane ROW was adjacent to a ROW maintained by PP\&L utility company.

We counted only those trees within a given transect belt (i.e., trees rooted outside a belt with foliage extending into the belt were not counted). Using these data, we calculated the density of target trees (no./ha) in each treatment unit and zone. In addition, we noted the maximum height $(\mathrm{m})$ of target trees in both wire and border zones of each unit in the vicinity of each transect belt. We also determined plant cover types within a $5 \mathrm{~m}$ (16.4 ft) radius plot placed in the center of each transect belt in wire and border zones of each unit, using the Braun-Blanquet method for estimating abundance and sociability of major plants. From these several estimates within each treatment unit, we calculated plant cover type(s) in each unit as forb, grass, shrub, tree, or a combination of these.

\section{RESULTS AND DISCUSSION Vegetation in 1999 Prior to Treatments in June 1999}

Excellent to moderate control of target trees was observed in herbicidal units. Excellent control of target trees was noted in wire zones of mowing plus herbicide units (618642 trees/ha [250-260 trees/ac]), even though 12 years had elapsed since the 1987 treatment (Yahner et al. 1999). Moderate tree density (741-1,976 trees/ha [300-800 trees/ac]) was typical in wire zones of stem-foliage and foliage spray units. In contrast, tree control was poor in wire zones of mechanical units (mowing: 4,446-5,311 trees/ha [1,800-2,150 trees/ac]; handcut: 4,570 trees/ha [1,850 trees/ac]). Tree density in border zones of all units, except handcut, averaged 2,668 trees/ha (1,080 trees/ac); in handcut, density was 3,458 trees/ha (1,400 trees/ac). 
Maximum tree height on the Green Lane ROW averaged $4.3 \mathrm{~m} \mathrm{(14ft)}$ and $4.9 \mathrm{~m}(16 \mathrm{ft})$ in wire and border zones, respectively (Yahner et al. 1999). Hence, trees were dangerously tall and in need of cutting to prevent possible power outages.

Immediately prior to the 1999 treatment of the Green Lane ROW, cover types in wire zones of herbicidal units (mowing plus herbicide, stem-foliage spray, and foliage spray) were classified as shrub-forb-grass-tree, whereas types in border zones of these units were tree-shrub-forb (Bramble et al. 1998). Both wire and border zones of mechanical units (mowing and handcut) were considered tree-shrub-forb cover type.

\section{Vegetation in 2003 and 2004}

The overall density of target trees in 2004 in all treatment units combined averaged 1,635 trees/ha [662 trees/ac] in wire zones and 1,894 trees/ha [767 trees/ac] in border zones (Table 1) (Yahner et al. 2003a; Yahner and Hutnik 2004a). Compared to densities noted in 2003, this represented only a $7.3 \%$ increase from the average overall density in wire zones ( 1,524 trees/ha [617 trees/ac] in 2003) but a $26.4 \%$ increase from the density in border zones (1,499 trees/ha [607 trees/ac] in 2003).

The overall densities of target trees, especially in wire zones, were influenced greatly by combining mechanical and herbicidal units (Table 1). For instance, if only wire zones of herbicidal units are considered, there were only 687 trees/ha (278 trees/ac) in 2003 and 728 trees/ha (295 trees/ac) in 2004. Yet, these densities in 2003-2004 were higher than those noted in 1999 prior to the last treatment. Hence, subsequent to a treatment, annual increases in target tree densities were expected as trees gradually invaded shrub, forb, and grass cover types, but these low densities in herbicidal units attest, in part, to the effectiveness of IVM for maintenance of electric utility transmission ROW (Bramble and Byrnes 1996).

Densities of target trees in border zones differed somewhat from those in wire zones in 2003 and 2004 (Table 1) (Yahner and Hutnik 2004a). Within most treatment units, there was no relationship between tree densities in wire zones versus adjacent border zones. In part, this was because border zones of each treatment unit were treated similarly in 1987, 1993, and 1999, and we should not expect any particular trends in tree densities among border zones of various treatment units. In fact, densities of trees actually declined in mechanical units between 2003 and 2004. From 1999-2004, the most common target tree species on the Green Lane ROW was white ash (Fraxinus americana); other relatively common target tree species were sassafras (Sassafras albidum), black cherry (Prunus serotina), eastern red cedar (Juniperus virginiana), and red maple (Acer rubrum).

By 2004 , the maximum tree height averaged $4.8 \mathrm{~m}(15.7 \mathrm{ft})$ in

$1,757(711)$

Herbicidal units combined Average

$687(278)$

$728(295)$

$1,058(428)$ 
Table 2. Cover type in wire zones and border zones of ten treatment units at the Green Lane Research and Demonstration Area in June 2003 and June 2004. F = forb, $G=$ grass, $S=$ shrub, and $T=$ tree. The symbol ">" implies a greater proportion of this cover type; the symbol "=" implies relatively similar amounts of this cover type.

\begin{tabular}{|c|c|c|c|c|}
\hline \multirow[b]{3}{*}{ Treatment/replicate unit } & \multicolumn{4}{|c|}{ Cover type } \\
\hline & \multicolumn{2}{|c|}{ Wire zone } & \multicolumn{2}{|c|}{ Border zone } \\
\hline & 2003 & 2004 & 2003 & 2004 \\
\hline \multicolumn{5}{|l|}{$\begin{array}{l}\text { Mechanical units } \\
\text { Handcut }\end{array}$} \\
\hline $\mathrm{HC}-1$ & $\mathrm{~S}>\mathrm{F}>\mathrm{T}$ & $\mathrm{S}>\mathrm{T}$ & $S>t$ & $S>F$ \\
\hline HC-2 & $S>T=F$ & $\mathrm{~S}>\mathrm{T}=\mathrm{F}$ & $S=F$ & $S=F$ \\
\hline \multicolumn{5}{|l|}{ Mowing } \\
\hline M-1 & $\mathrm{F}>\mathrm{S}$ & $\mathrm{S}>\mathrm{F}$ & $\mathrm{S}>\mathrm{F}>\mathrm{T}$ & $\mathrm{S}>\mathrm{F}>\mathrm{G}$ \\
\hline M-2 & $S=F$ & $\mathrm{~F}>\mathrm{S}>\mathrm{G}$ & $\mathrm{S}>\mathrm{F}$ & $\mathrm{S}>\mathrm{F}$ \\
\hline \multicolumn{5}{|l|}{$\begin{array}{l}\text { Herbicidal units } \\
\text { Mowing plus herbicide }\end{array}$} \\
\hline $\mathrm{MH}-1$ & $G>F>S$ & $G>S=F$ & $S=F$ & $\mathrm{~S}>\mathrm{F}=\mathrm{G}$ \\
\hline MH-2 & $\mathrm{F}=\mathrm{G}>\mathrm{S}$ & $S>G>F$ & $S>F$ & $\mathrm{~S}>\mathrm{F}>\mathrm{G}$ \\
\hline \multicolumn{5}{|l|}{ Foliage spray } \\
\hline $\mathrm{F}-1$ & $\mathrm{~F}>\mathrm{G}>\mathrm{S}$ & $\mathrm{F}>\mathrm{G}>\mathrm{S}$ & $\mathrm{S}>\mathrm{G}>\mathrm{F}$ & $\mathrm{S}=\mathrm{G}=\mathrm{F}$ \\
\hline $\mathrm{F}-2$ & $\mathrm{~S}>\mathrm{F}>\mathrm{G}$ & $F=G>S$ & $\mathrm{~S}>\mathrm{F}$ & $\mathrm{S}>\mathrm{F}$ \\
\hline \multicolumn{5}{|l|}{ Stem-foliage spray } \\
\hline SF-1 & $F>S$ & $F>S$ & $\mathrm{~S}>\mathrm{F}$ & $S>F$ \\
\hline SF-2 & $F>G>S$ & $S=F$ & $F>S>G$ & $S=F$ \\
\hline
\end{tabular}

wire zones and $6.7 \mathrm{~m}(22.0 \mathrm{ft})$ in border zones on the Green Lane Research and Demonstration Area (Yahner and Hutnik 2004a). As a consequence of these heights of target trees, which were greater than those recorded in 1999 prior to the last treatment, the Green Lane ROW was treated again in July-August 2004.

In both 2003 and 2004, shrubs and forbs were the most important cover types in wire zones of all treatment units, but grass cover type was important in wire zones of five of the ten units (Table 2) (Yahner and Hutnik 2004a). These results were similar to those observed in 1999 on the Green Lane ROW. Trees were a major cover type in handcut units. If vegetation were sampled in late July rather than earlier in the year, forbs perhaps would be better represented in cover types. The major shrub in wire zones of all units was Rubus, whereas the principal shrub in border zones was Japanese honeysuckle (Lonicera japonica). Goldenrod (Solidago spp.) was the dominant forb in most treatment units.

IVM of a ROW is a "tree resistant" but not a "tree proof " means of reducing tree invasion (Bramble et al. 1996). Competition with existing plants and wildlife predation on tree seeds on a ROW managed via the wire-border zone method keep tree invasion to a minimum. Thus, over the years since 1987, IVM and the wire-border zone method of ROW maintenance have increased the time between treatment cycles, thereby reducing labor and chemical costs for maintenance (Bramble et al. 1996; Yahner and Hutnik 2004b).
In summary, the plant community present on the Green Lane Research and Demonstration Area has remained relatively stable over the years since the onset of IVM and the wire-border zone method of maintenance in 1987. The result has been an excellent demonstration of how ROW maintenance can have multiple benefits to utility companies and wildlife (e.g., Yahner 2004). Recently, electric utility companies have recommended that IVM and the wireborder zone method be used on both new and existing ROW to mitigate undesirable tree invasion and possible power outages in the future (Burns 2004).

\section{LITERATURE CITED}

Bramble, W.C., and W.R. Byrnes. 1996. Integrated vegetation management of an electric utility right-ofway ecosystem. Down to Earth 51(1):29-34.

Bramble, W.C., W.R. Byrnes, R.J. Hutnik, and S.A. Liscinsky. 1991. Prediction of cover type on rights-ofway after maintenance treatments. J. Arboric. 17:38-43.

— 1996. Interference factors responsible for resistance of forb-grass cover types to tree invasion on an electric right-of-way. J. Arboric. 22:99-105.

Bramble, W.C., W.R. Byrnes, R.J. Hutnik, S.A. Liscinsky, and R.H. Yahner. 1998. Green Lane Research Project. Annual Report to Cooperators. School of Forest Resources, Penn State University, University Park, PA. 26 pp.

Burns, M.F. (Ed.) 2004. Utility Vegetation Management Final Report. CN Utility Consulting, LLC, Novato, CA. $128 \mathrm{pp}$.

Yahner, R.H. 2004. Wildlife response to over 50 years of vegetation maintenance on a Pennsylvania right-of-way. J. Arboric. 30:123-126.

Yahner, R.H., and R.J. Hutnik. 2004a. Green Lane Research and Demonstration Project: 18 Years of continuous study. Annual Report to Cooperators. School of Forest Resources, Penn State University, University Park, PA. 28 pp. 2004b. Integrated vegetation management on an electric transmission right-of-way in Pennsylvania, U.S. J. Arboric. 30:295-300.

Yahner, R.H., R.J. Hutnik, and S.A. Liscinsky. 2003a. Green Lane Research and Demonstration Project: 17 Years of Continuous Study. Annual Report to Cooperators. School of Forest Resources, Penn State University, University Park, PA. 28 pp.

_ 2003b. State Game Lands 33 Research and Demonstration Project: 51 Years of Continuous Study. Annual Report to Cooperators. School of Forest Resources, Penn State University, University Park, PA. 38 pp.

Yahner, R.H., W.C. Bramble, W.R. Byrnes, R.J. Hutnik, and S.A. Liscinsky. 1999. Green Lane Research Project. Annual Report to Cooperators. School of Forest Resources, Penn State University, University Park, PA. 37 pp. 
Acknowledgments. Cooperators were Asplundh Tree Expert Tree Company, Dow AgroSciences, and PECO Energy. Thanks are extended to Environmental Consultants, Inc. Also, we appreciate the assistance of E. Hill in preparing this manuscript.

\author{
${ }^{1,2}$ School of Forest Resources \\ The Pennsylvania State University \\ University Park, PA, 16802, U.S.
}

Corresponding author: Richard H. Yahner.

Résumé. La gestion intégrée de la végétation au moyen de la méthode des zones sous et en bordure des fils a été utilisée pour le contrôle de la végétation au sein de l'emprise de ligne de transport d'électricité de l'Aire de démonstration et de recherche de Green Lane du comté de Montgomery en Pennsylvanie, et ce depuis 1987. La méthode de la zone sous et en bordure des fils crée un couvert en graminées et arbustes de petite taille dans les zones sous les fils et un couvert arbustif haut au sein des zones en bordure des fils. LAire de démonstration et de recherche de Green Lane a été étudiée annuellement depuis 1987, ce qui fait de ce projet âgé de 18 ans l'une des études continues les plus longues pour documenter les effets du contrôle mécanique et chimique sur la flore et la faune le long de cette emprise de transport d'électricité. Dans cet article, notre objectif est de présenter le niveau cible de densité en arbres et le développement du couvert type afin de répondre aux objectifs de la gestion intégrée de la végétation en fonction de l'intervention la plus récente (juin 1999) et ses résultats 4 à 5 ans plus tard. Un excellent contrôle des arbres cibles a été noté en 1999 au sein des zones sous les fils qui étaient fauchées avec herbicide; par contre, le contrôle des arbres était faible au sein des zones sous les fils qui étaient traitées mécaniquement (fauchage et coupe manuelle). La hauteur maximale des arbres était de 4,3 m et 4,9 m en moyenne, respectivement au sein des zones sous les fils et des zones en bordure des fils.

Immédiatement avant l'intervention de 1999 au sein de l'emprise de Green Lane, les types de couvert végétal dans les zones sous les fils d'unités traitées par herbicide (fauchage avec herbicide, vaporisation foliaire et sur les tiges, vaporisation foliaire) ont été classifiés en arbustes-herbacées-graminées-arbres, tandis que les zones en bordure des fils ont été classifiées en arbres-arbustes-herbacées. Le couvert des unités traitées mécaniquement, à la fois dans les zones sous les fils et celles en bordure, a été classifié en arbres-arbustes-herbacées. La densité globale en arbres cibles s'était accrue de 7,3 et 26,4\%, respectivement au sein des zones sous les fils et en bordure de ces derniers, et ce en 2004 comparativement à 2003. De 1999 à 2004, l'espèce d'arbre cible la plus commune était le frêne d'Amérique (Fraxinus americana) au sein de l'emprise de Green Lane. À la fois en 2003 et 2004, les arbustes et les herbacées constituaient les types de couvert les plus importants au sein de toutes les unités traitées dans la zone sous les fils; cependant, le couvert en graminées était important au sein de 5 des 10 unités de la zone sous les fils. La gestion intégrée de la végétation au sein des emprises se définit comme une résistance, et non une élimination, de l'invasion par les arbres. La compétition qui existe entre les végétaux et la prédation faunique sur les semis d'arbres d'une emprise gérée via la méthode des zones sous et en bordure des fils permet de maintenir l'invasion par les arbres à un niveau minimal. De cette manière depuis 1987, la gestion intégrée de la végétation au moyen de la méthode des zones sous et en bordure des fils pour l'entretien d'une emprise a permis d'accroître le délai du cycle de retour des traitements, ce qui a permis de diminuer la charge de travail et les coûts en produits chimiques pour l'entretien de l'emprise.

Zusammenfassung. Seit 1987 wird in der Green Lane Research and Demonstration Area, Montgomery County, Pennsylvania, USA, die Methode des Integrierten Pflanzenschutz (IPS) via GrenzbereichMethode eingesetzt, um die Vegetation im Bereich der Überlandleitungen zu pflegen und erhalten. Die Grenzbereich-Methode kreiert unter den Leitungen eine niedrige Gras-Busch-Bedeckung und im Grenzbereich höhere Büsche. Die Green Lane Research and Demonstration Area wird seit 1987 jährlich untersucht, was dieses 18 Jahre alte Projekt zur ältesten Dauerstudie über die Auswirkung von Pflegemaßnahmen im Bereich von Überlandleitungen macht. In dieser Studie ist unser Ziel, die Dichte von unerwünschten Baumarten und Bedeckungstypenentwicklung in Bezug auf IPS bei der jüngsten Behandlung (Juni 1999) und 4-5 Jahre nach der Behandlung zu untersuchen. Eine ausgezeichnete Überwachung unerwünschter Baumarten wurde 1999 in Leitungsbereichen mit Mähen und Herbizidbehandlungen notiert. Im Kontrast dazu war die Kontrolle in Leitungsbereichen mit mechanischer Behandlung sehr dürftig. Die maximale Baumhöhe reichte von 4,3 $\mathrm{m}$ bis 4,9 $\mathrm{m}$ unter bzw. neben Leitungsbereichen. Sofort nach der Behandlung 1999 wurden die Bedeckungstypen in Leitungsbereichen mit Herbizidbehandlung klassifiziert als Busch-Strauch-Gras-Baum-Typ und die Randbereiche als Baum-Busch-Strauch-Typ. Beide Bereiche mit mechanischer Pflege wurden als Baum-Busch-Strauch-Typ identifiziert. Die allgemeine Dichte von unerwünschten Bäumen stieg um 7,3 \% bzw. 26,4 \% in Leitungszonen und Randzonen in 2004, verglichen zu 2003. Von 1999 bis 2004 war die häufigste unerwünschte Baumart Fraxinus americana. In 2003 und 2004 waren Busch und Strauch-Bereiche die wichtigsten Bedeckungstypen unterhalb der Leitungen bei allen Behandlungsmethoden. Der GrasTyp war bei 5 von 10 Einheiten unterhalb der Leitungen wichtig. IPS bei Überlandleitungen ist in Bezug auf Invasion von unerwünschten Pflanzen hilfreich, aber nicht todsicher. Der Kampf mit bereits vorkommenden Pflanzen und der Samenverbreitung durch Tiere in einer durch die Grenzzonen-Methode gepflegten Überlandleitung hält die Invasion durch unerwünschte Arten auf ein Minimum. Daher hat sich über die Jahre seit 1987 die Zeit zwischen den Behandlungszyklen verlängert und nachfolgend die Kosten für Arbeit und Chemikalien in der Pflege reduziert.

Resumen. El Manejo Integrado de la Vegetación (MIV) con el método de zona de frontera y alambrada ha sido usado desde 1987 para el mantenimiento de la vegetación a largo del derecho de vía (ROW) de una línea de transmisión eléctrica en el Área de Demostración e Investigación Green Lane, Condado de Montgomery, Pennsylvania, U.S. El método de zona de frontera crea un tipo de cobertura arbustiva baja y en zonas alambradas crea un tipo alto de cobertura. El área de investigación y demostración ha sido estudiada anualmente desde 1987, lo cual hace de este proyecto de 18 años uno de los más largos y continuos estudios documentando los efectos del mantenimiento mecánico y herbicida de flora y fauna a lo largo de la línea de transmisión eléctrica ROW. En este reporte, nuestro objetivo es presentar la densidad de árboles óptima y el desarrollo del tipo de cobertura en respuesta a MIV antes de los tratamientos (Junio 1999) y 4-5 años después de los mismos. Se encontró excelente control de los árboles objetivo en 1999 en zonas alambradas de 
unidades con tratamiento de cegadoras más herbicidas; en contraste, el control de los árboles fue pobre en zonas alambradas de unidades con tratamiento mecánico (segadoras más corta manual). El máximo promedio de altura de los árboles fue de $4.3 \mathrm{~m}$ (14 pies) y $4.9 \mathrm{~m}$ (16 pies) en zonas de frontera y alambradas, respectivamente.

Inmediatamente antes de 1999 en el tratamiento de la línea ROW, los tipos de cobertura en zonas alambradas de unidades herbicidas (segadora más herbicida, aspersión al follaje y spray al follaje) fueron clasificadas como árbol-pasto-arbusto, mientras los tipos en zonas de frontera de estas unidades fueron árbol-arbusto. Tanto las zonas de alambre como las zonas de frontera de unidades mecánicas fueron consideradas tipos de cobertura árbol-arbustos. Las densidad total de los árboles objetivo incrementó $7.3 \%$ y $26.4 \%$ en zonas de alambre y de frontera, respectivamente, en 2004 comparadas a 2003. Desde
1999-2004, la especie más común de árbol fue fresno blanco (Fraxinus americana). En ambos, 2003 y 2004, los arbustos fueron tipos de coberturas importantes en las zonas alambradas de todas las unidades de tratamiento; el tipo de cobertura de pasto, sin embargo, fue importante en zonas alambradas en cinco de 10 unidades. El MIV de un ROW es un "árboles resistente" pero no un "árbol a toda prueba" resultado de la invasión reducida de árboles. La competencia con las plantas existentes y la prelación de vida silvestre de semillas de árboles en un ROW, manejado vía el método de zona de frontera, mantiene la invasión de árboles al mínimo. Por consiguiente, desde 1987, el MIV, con el método de mantenimiento de zona de alambre del ROW, ha incrementado el tiempo entre ciclos de tratamiento, de allí que reduce el trabajo y los costos de mantenimiento. 